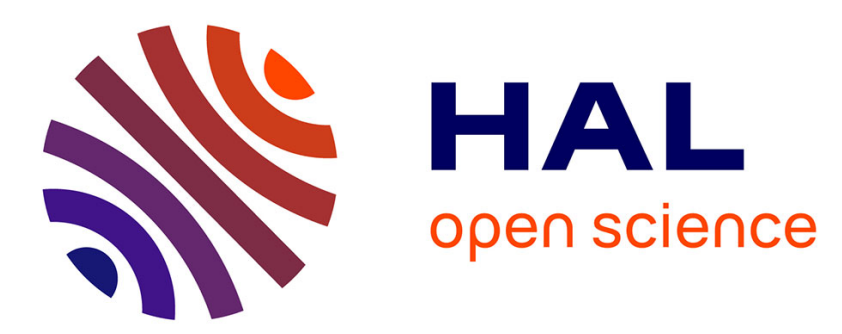

\title{
Tunable electrical properties of self-organized zirconia nanotubes
}

Florence Vacandio, Marielle Eyraud, Philippe Knauth, Thierry Djenizian

\section{To cite this version:}

Florence Vacandio, Marielle Eyraud, Philippe Knauth, Thierry Djenizian. Tunable electrical properties of self-organized zirconia nanotubes. Electrochemistry Communications, 2011, 13 (10), pp.10601062. 10.1016/j.elecom.2011.06.032 . hal-02656773

\section{HAL Id: hal-02656773 \\ https://hal-amu.archives-ouvertes.fr/hal-02656773}

Submitted on 5 Jun 2020

HAL is a multi-disciplinary open access archive for the deposit and dissemination of scientific research documents, whether they are published or not. The documents may come from teaching and research institutions in France or abroad, or from public or private research centers.
L'archive ouverte pluridisciplinaire HAL, est destinée au dépôt et à la diffusion de documents scientifiques de niveau recherche, publiés ou non, émanant des établissements d'enseignement et de recherche français ou étrangers, des laboratoires publics ou privés. 


\title{
Tunable electrical properties of self-organized zirconia nanotubes
}

\author{
Florence Vacandio*, Marielle Eyraud, Philippe Knauth, Thierry Djenizian \\ LCP, Electrochemistry of Materials Research Group, UMR 6264, Aix-Marseille University, CNRS, Campus de Saint-Jérôme, Marseille cedex 20, F-13 397, France
}

\section{A R T I C L E I N F O}

Keywords:

Zirconia nanotubes

Nanostructuration

Anodization

Electrical properties

\begin{abstract}
A B S T R A C T
Structural and electrical properties of self-organized zirconia nanotube layers can be tuned by a simple thermal treatment. The effect of $\mathrm{F}$ on the electrical conductivity of the $\mathrm{MO}_{\mathrm{x}}$ nanotubes grown by anodization in fluoride-containing electrolytes is demonstrated.
\end{abstract}

\section{Introduction}

Zirconia is known to have remarkable properties and to be an electrical insulator which can become a pure ionic conductor if doped $\left(\mathrm{Y}_{2} \mathrm{O}_{3}, \mathrm{Gd}_{2} \mathrm{O}_{3} \ldots\right)[1,2]$. This leads to technological applications such as industrial catalysts and catalyst supports [3], oxygen sensors [4], solid electrolyte fuel cells (SOFC) [5]. Pure zirconia can be found in three crystallographic structures: monoclinic until $1170^{\circ} \mathrm{C}$, tetragonal between $1170{ }^{\circ} \mathrm{C}$ and $2370{ }^{\circ} \mathrm{C}$ and cubic above $2370{ }^{\circ} \mathrm{C}$. However, only the tetragonal phase gives ceramics with satisfying mechanical properties. This phase can be stabilized at room temperature by doping with bivalent or trivalent cations, especially by yttrium. During the last decades, the use of porous materials has attracted attention in various domains and particularly in the field of energy. Porous materials have the advantage of large specific surface that can increase the performances of the materials while reducing the size and weigth of the components. A possible way to grow highly-ordered nanostructures is the anodization of valve metals such as Ti [6,7], Hf [8], $\mathrm{Zr}$ [9-16] in fluoride-containing electrolytes. Most of these nanostructured oxides are obtained by anodization of metallic foils, which limits their application in functional microdevices. An interesting alternative opening the path towards a wide range of applications is the anodization of thin films. Thus, in previous work, we have reported the synthesis of self-organized $\mathrm{TiO}_{2}$ nanotubes from sputtered Ti thin layers deposited on Si [17-24].

In this paper, we report the fabrication of $\mathrm{ZrO}_{2}$ nanotubes $\left(\mathrm{ZrO}_{2} \mathrm{nt}\right)$ by anodization of thin layers of $\mathrm{Zr}$ deposited by cathodic sputtering on Si substrates. We study the influence of annealing upon the

\footnotetext{
* Corresponding author. Tel.: + 33491 551837; fax: + 33491551850. E-mail address: florence.vacandio@univ-provence.fr (F. Vacandio).
}

morphological, structural and electrical properties of nanotubes by Scanning Electron Microscopy (SEM), Energy Dispersive Spectrocopy (EDS), X-ray Diffraction (XRD) and Electrochemical Impedance Spectrocopy (EIS) measurements.

\section{Experimental section}

Zirconium thin films were deposited by cathodic sputtering using a DC triode system on Si substrates $\left(4 \times 4 \mathrm{~cm}^{2}\right)$ prepared from p-type $\mathrm{Si}(100)$ wafers with a resistivity of $1-10 \Omega . \mathrm{cm}$ (Wafer World, Inc.). In order to remove the native oxide layer, the Si samples were dipped in $1 \% \mathrm{HF}$ solution for $30 \mathrm{~s}$, then rinsed in deionized (DI) water and dried under a nitrogen stream before being introduced into the chamber. $A$ $\mathrm{Zr}$ metal disk (nominal purity 99.9\%, diameter $5 \mathrm{~cm}$ ) was the sputtering target and the base chamber pressure prior to depositions was kept as low as $10^{-7}$ mbar. The high-purity argon pressure and the target current during deposition were maintained at constant values of $7.10^{-4} \mathrm{mbar}$ and $150 \mathrm{~mA}$, respectively. Under these conditions, the deposition rate was $16 \mathrm{~nm} \mathrm{~min}{ }^{-1}$ and a $2.6 \mu \mathrm{m}$ thick $\mathrm{Zr}$ film was obtained after $120 \mathrm{~min}$. Zirconium layers were anodized at room temperature at $40 \mathrm{~V}$ during $10 \mathrm{~min}$ with a conventional twoelectrode configuration, using an EG\&G PARSTAT 2273 potentiostat/ galvanostat. A platinum grid was used as counter electrode. The electrodes were immersed in a $0.35 \mathrm{M} \mathrm{NH}_{4} \mathrm{~F}, 5 \%$ vol. water and glycerol electrolyte.

Impedance measurements were performed in a $1 \mathrm{M}\left(\mathrm{NH}_{4}\right)_{2} \mathrm{SO}_{4}$ solution with in addition to the previous configuration a reference Calomel Saturated Electrode (ECS), using a Potentiostat-Galvanostat coupled with a Frequency Response Analyser (Solartron 1287 and 1260). Impedance diagrams were recorded at open circuit potential, with a signal amplitude of $20 \mathrm{mV}$ and a frequency range starting from $100 \mathrm{kHz}$ to $10 \mathrm{mHz}$. Samples were analyzed by X-Ray Diffraction 
(XRD) with $\mathrm{CuK} \alpha$ radiation $(\lambda=0.15406 \mathrm{~nm}$ ) using a Siemens D5000 diffractometer; the processing software is BRUKER Diffrac-eva. Scanning Electron Microscopy (SEM) observations were performed using a Philips XL 30 ESEM equipped with an energy-dispersive X-Ray spectrometer (EDS).

\section{Results and discussion}

The SEM images (Figs. 1 and 2) show the morphology of the selforganized zirconia nanotubes before and after annealing at $450{ }^{\circ} \mathrm{C}$ during $3 \mathrm{~h}$ in air. The as-formed porous layer exhibits an uniform and ordered nanotube arrangement. The diameters of the $\mathrm{ZrO}_{2}$ tubes are around $25-30 \mathrm{~nm}$ and the wall thickness is estimated to be approximately $5 \mathrm{~nm}$. The examination of the SEM cross-section (not shown) reveals that the thickness of the $\mathrm{ZrO}_{2}$ nt layer is about $2.1 \mu \mathrm{m}$. Additionally, the presence of a remaining zirconium layer of about $0.8 \mu \mathrm{m}$ indicates a thickness increase of $11.5 \%$ as the thickness of the sputtered zirconium layer was $2.6 \mu \mathrm{m}$. After the thermal treatment, it can be noticed that the nanoporous matrix does not collapse and is not damaged (no fissure or crack can be seen by SEM). Although a fraction of the tubes are plugged, it is remarkable that the morphology as well as the dimensions of the nanotubes are still preserved.

The corresponding Energy Dispersive X-Ray Spectroscopy (EDS) spectra exhibit two peaks relative to $\mathrm{Zr}$ and $\mathrm{O}$. However, as-prepared $\mathrm{ZrO}_{2}$ nt shows a peak attributed to the presence of $\mathrm{F}$ in the oxide matrix. Insertion of $\mathrm{F}$ is supposed to take place during the anodization process through the decomposition of the F-containing electrolyte leading to the probable formation of a thin $\mathrm{ZrF}_{4}$ layer embedding the external surface of the nanotubes. The formation of such a thin layer has been reported in the case of the electrochemical fabrication of titania nanotubes [25]. Another scenario for the incorporation of $\mathrm{F}$ could also be substitution of an oxygen atom by a fluorine atom in the oxide bulk near the surface. After annealing, the absence of the peak corresponding to fluorine suggests that it might evaporate as HF during the thermal treatment.

In Fig. 3 are presented the XRD patterns of the as-prepared and annealed $\mathrm{ZrO}_{2}$ nt layers. The pattern for non-annealed sample shows the presence of a small peak at $2 \theta=34.9^{\circ}$ relative to the residual layer of hexagonal zirconium (JCPDS file $\mathrm{N}^{\circ} 005-0665$ ). Four peaks located at $2 \theta=28.3 ; 31.5 ; 34.5$ and 51.1 are attributed to the $\mathrm{ZrO}_{2}$ monoclinic phase (JCPDS File No 037-1484) and one peak at $2 \theta=50.6$ to the tetragonal phase (JCPDS File No 050-1089). After annealing, both monoclinic and tetragonal phases are still detected, but two additional intense peaks corresponding to the tetragonal modification appear revealing an increased proportion of tetragonal phase. This result shows that a simple annealing treatment can promote the phase that is known to exhibit good mechanical properties [26].

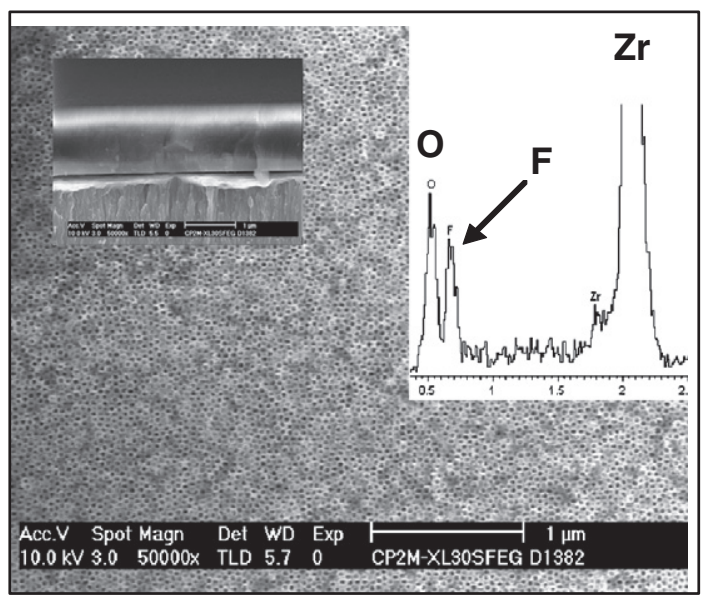

Fig. 1. SEM observation and EDS analysis of as-formed $\mathrm{ZrO}_{2}$ nt.

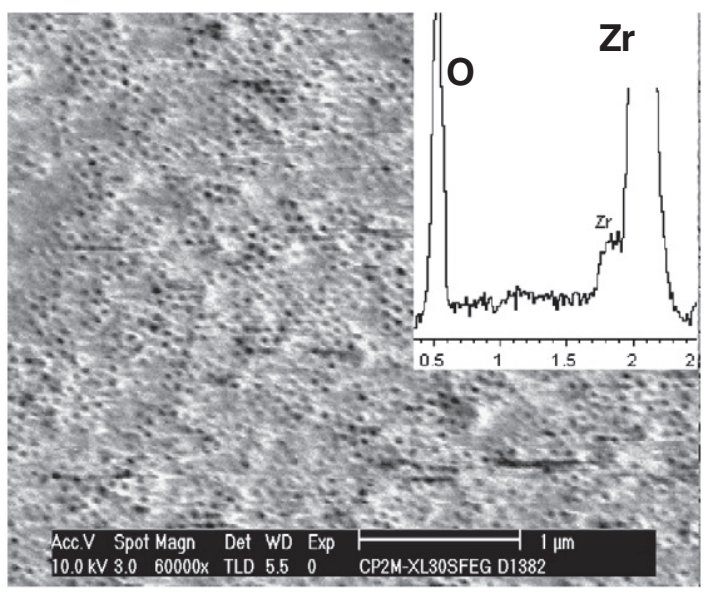

Fig. 2. SEM observation and EDS analysis of $\mathrm{ZrO}_{2}$ nt after annealing.

Electrical properties of $\mathrm{ZrO}_{2}$ nt before and after annealing were investigated by Electrochemical Impedance Spectroscopy (Fig. 4). The modulus of the impedance at high frequency is a good approximation of the resistance of the layer. The impedance modulus at low frequency is equal to $1.710^{5} \Omega \cdot \mathrm{cm}^{2}$ for the as-formed $\mathrm{ZrO}_{2}$ nt layer and equal to $3.10^{8} \Omega \cdot \mathrm{cm}^{2}$ after annealing. While the insulating behaviour of the annealed $\mathrm{ZrO}_{2}$ nt layer is comparable to pure zirconia reported in literature, the unexpected semiconductor behaviour observed before annealing can be explained by the presence of fluorine in the structure. Indeed, the insertion of fluorine ions occupying oxygen ion sites is responsible for the generation of excess electrons, as described in Kröger-Vink notation:

$\mathrm{O}_{\mathrm{O}}+\mathrm{F}=1 / 2 \mathrm{O}_{2}+\mathrm{F}_{\mathrm{O}}^{\circ}+\mathrm{e}^{\prime}$

Thus, fluoride ions incorporated into zirconia nanotubes have a strong effect on the electrical properties, enhancing n-type conductivity. In contrary, the annealing in oxygen-containing atmosphere removes both $\mathrm{F}$ and electrons in $\mathrm{ZrO}_{2} \mathrm{nt}$, as can be immediately concluded by reversing eq. (1). Clearly, the electrical conductivity of $\mathrm{ZrO}_{2}$ nt decreases drastically when fluorine is removed from the structure. This is the first evidence of the direct effect of $\mathrm{F}^{-}$upon the electrical properties of $\mathrm{MO}_{\mathrm{x}}$ nanotubes prepared by electrochemical techniques. So far, this effect has been hidden by the intrinsic electrical behaviour of the studied materials; this is especially the case for $\mathrm{TiO}_{2}$ nt that remains semiconducting. More generally, the results presented in this work demonstrate that the electrical properties of $\mathrm{MO}_{\mathrm{x}}$ nt layers formed by anodization in fluoride-containing electrolytes could be tuned by an appropriate thermal treatment.

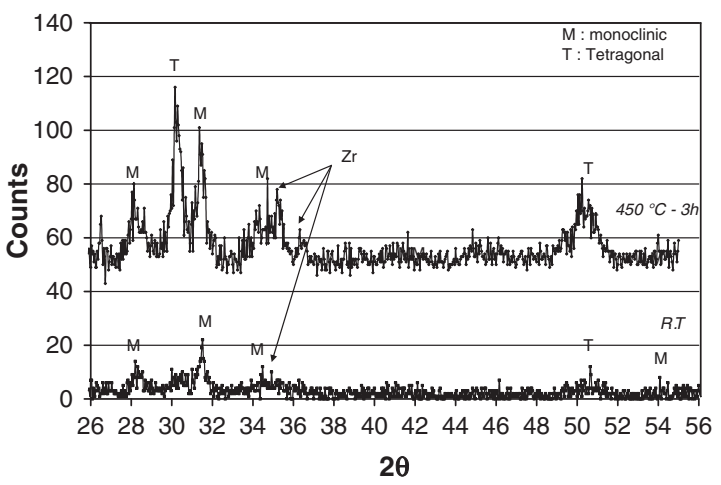

Fig. 3. X-Ray diffraction (XRD) diagrams of $\mathrm{ZrO}_{2}$ nt before and after annealing. 


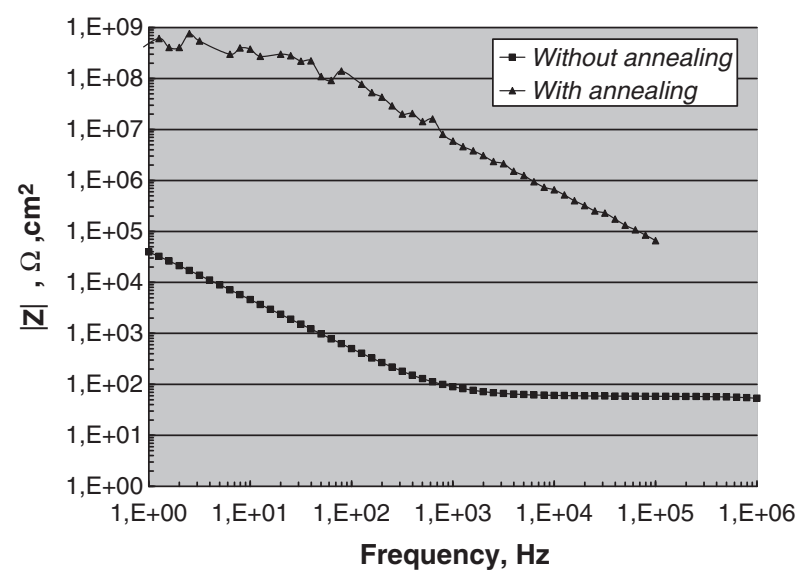

Fig. 4. Electrochemical impedance spectra of $\mathrm{ZrO}_{2}$ nt before and after annealing.

\section{Conclusion}

Electrochemical fabrication of zirconia nanotube thin films is described in fluoride-containing electrolyte. The annealing at $450{ }^{\circ} \mathrm{C}$ during $3 \mathrm{~h}$ in air does not affect the nanotubular morphology, but changes drastically the structural and electrical properties. Indeed, thermal treatment leads to an increase of the proportion of tetragonal phase, which is the most interesting due to the good mechanical properties. More remarkably, the electrical conductivity of the $\mathrm{ZrO}_{2} \mathrm{nt}$ layer can be also turned from semiconductor to insulator after fluorine removal. This is the first evidence of the effect of $F$ on the electrical properties of $\mathrm{MO}_{\mathrm{x}}$ nanotubes fabricated by anodization of fluoridecontaining electrolytes.

\section{References}

[1] L.J. Gauckler, K. Sasaki, Solid State Ionics 75 (1995) 203.

[2] C. Korte, A. Peters, J. Janek, D. Hesse, N. Zakharov, Phys. Chem. Chem. Phys. 10 (31) (2008) 4623.

[3] I. Atribak, I. Such-Basaniez, A. Bueno-Lopez, A. Garcia-Garcia, J. Catal. 250 (1) (2007) 75.

[4] G.-L. Tan, X.-J. Wu, Thin Solid Films 330 (2) (1998) 59.

[5] G. Laukaitis, J. Dudonis, D. Milcius, Thin Solid Films 515 (2) (2006) 678.

[6] J.M. Macak, H. Hildebrand, U. Marten-Jahns, P. Schmuki, J. Electroanal. Chem. 621 (2) (2008) 254.

[7] J.M. Macak, P. Schmuki, Electrochim. Acta 52 (3) (2006) 1258.

[8] S. Berger, F. Jakubka, P. Schmuki, Electrochem. Solid St. 12 (7) (2009) K45.

[9] J. Zhao, X. Wang, R. Xu, F. Meng, L. Guo, Y. Li, Mater. Lett. 62 (29) (2008) 4428.

[10] X. Montero, T. Pauporté, A. Ringuedé, R.-N. Vannier, M. Cassir, J. Power Sources 151 (2005) 85.

[11] J. Zhao, R. Xu, X. Wang, Y. Li, Corros. Sci. 50 (6) (2008) 1593.

[12] K. Yasuda, P. Schmuki, Electrochem. Commun. 9 (4) (2007) 615.

[13] S. Berger, F. Jakubka, P. Schmuki, Electrochem. Commun. 10 (12) (2008) 1916.

[14] H. Tsuchiya, J.M. Macak, L. Taveira, P. Schmuki, Chem. Phys. Lett. 410 (4-6) (2005) 188.

[15] F. Trivinho-Strixino, F.E.G. Guimarães, E.C. Pereira, Chem. Phys. Lett. 461 (1-3) (2008) 82.

[16] H. Tsuchiya, P. Schmuki, Electrochem. Commun. 6 (11) (2004) 1131.

[17] G.F. Ortiz, I. Hanzu, P. Lavela, J.L. Tirado, P. Knauth, T. Djenizian, J. Mater. Chem. 20 (20) (2010) 4041.

[18] G.F. Ortiz, I. Hanzu, P. Knauth, P. Lavela, J.L. Tirado, T. Djenizian, Electrochim. Acta 54 (17) (2009) 4262.

[19] T. Djenizian, I. Hanzu, Y.D. Premchand, F. Vacandio, P. Knauth, Nanotechnology (2008) 19-20.

[20] F. Vacandio, M. Eyraud, C. Chassigneux, P. Knauth, T. Djenizian, J. Electrochem. Soc. 157 (12) (2010) K279.

[21] Y.D. Premchand, T. Djenizian, F. Vacandio, P. Knauth, Electrochem. Commun. 8 (12) (2006) 1840

[22] G.F. Ortiz, I. Hanzu, T. Djenizian, P. Lavela, J.L. Tirado, P. Knauth, Chem. Mat. 21 (1) (2009) 63.

[23] G.F. Ortiz, I. Hanzu, P. Knauth, P. Lavela, J.L. Tirado, T. Djenizian, Electrochem. Solid St. 12 (9) (2009) A186.

[24] I. Hanzu, T. Djenizian, P. Knauth, J. Phys. Chem. C 115 (13) (2011) 5989

[25] T. Ruff, R. Hahn, P. Schmuki, Appl. Surf. Sci., in press, Corrected Proof (2011)

[26] K. Morita, K. Hiraga, Acta Mater. 50 (5) (2002) 1075. 